\title{
Citra Kampung Adat Cireundeu pada Ritual Suraan
}

\author{
Fauzan Ahdi Widyaputra ${ }^{1}$, Evi Novianti ${ }^{2}$, dan Iriana Bakti ${ }^{3}$ \\ ${ }^{1}$ Dinas Kebudayaan dan Pariwisata Budaya Kota Padang \\ ${ }^{2,3}$ Universitas Padjadjaran
}

\begin{abstract}
ABSTRAK
Cireundeu merupakan salah satu kampung adat di Jawa Barat yang sampai saat ini masih memelihara tradisi kearifan lokal berupa ritual Suraan yang diselenggarakan setiap tahun. Melalui tradisi ini, Cireundeu berusaha mempertahankan citra sebagai Kampung Adat yang masih mempertahankan tradisi peninggalan jaman dahulu di tengah modernisasi. Ritual ini pada dasarnya merupakan kegiatan komunikasi yang sarat dengan simbol yang mengandung makna. Studi ini bertujuan untuk menjelaskan tentang aktivitas komunikasi yang dilakukan masyarakat Kampung Adat Cireundeu. Metode yang digunakan dalam penelitian ini adalah deskriptif, dengan sifat data kualitatif. Teknik pengumpulan data menggunakan observasi partisipatif, wawancara dengan informan yang menjadi pelaku ritual, dan studi kepustakaan yang relevan dengan masalah yang diteliti. Hasil penelitian menunjukkan bahwa ritual upacara Satu Sura ini merupakan manifestasi dari rasa syukur masyarakat adat Cireundeu atas keberkahan yang diberikan Sang Pencipta, dan menjadi alat kontrol dalam tindakan atau pergaulan antar sesama manusia. Perilaku komunikasi yang terlihat pada aktivitas ritual Suraan ini termasuk pada perilaku terbuka, karena semua orang diperkenankan untuk terlibat di dalamnya untuk mengekspresikan perasaannya, sehingga masyarakat Kampung Adat Cireundeu merespons stimulus dalam hal ini rangkaian ritual dengan bentuk tindakan dan praktek (practice), sehingga masyarakat melakukan komunikasi sesuai dengan kebutuhannya. Citra yang terbangun pada Kampung Adat Cireundeu adalah kampung yang masih memelihara kearifan lokal di tengah modernisasi.
\end{abstract}

Kata-kata Kunci: Citra; kampung adat; komunitas adat; perilaku komunikasi; ritual suraan

\section{Image of Cireundeu Indigenous Village Through Suraan Rituals}

\begin{abstract}
Cireundeu is one of a traditional village in West Java, which still maintains the tradition of local wisdom in the form of Suraan ritual held every year. Through this tradition, Cireundeu tried to maintain the image of an Indigenous Village which still retains ancient the heritage traditions amidst modernization. The purpose of this study is to gain an empirically about a communication event Kampung Cireundeu Indigenous Communities in terms of the meaning of symbols Suraan ritual performed by the village of Indigenous communities Cireundeu. The method used in this article is a qualitative - ethnography of communication, with data collection techniques are participatory observation, interview with informants who become ritual actors, and literature studies that are relevant to the problem under study. The results of the study showed that the ritual of the Satu Sura ceremony was a manifestation of the gratitude of the Cireundeu indigenous people for the blessings given by God, and became a means of control in actions or relationships among fellow humans. Communication behavior seen in the ritual activities of Suraan is included in open behavior, because all people are allowed to be involved in it to express their feelings, so that the people of Indigenous Village Cireundeu respond to stimulus in this case a series of rituals with forms of practice and practice communication according to their needs. The image that was built in the Cireundeu Traditional Village is a village that still maintains local wisdom amidst modernization.
\end{abstract}

Keywords: Communication behavior; image; indigenous communities; indigenous village; ritual suroan

Korespondensi: Fauzan Ahdi Widyaputra, M.I.Kom. Dinas Kebudayaan dan Pariwisata. Jl. Samudera No.1, Belakang Tangsi, Padang, Kota Padang, Sumatera Barat, Indonesia. Email: fauzan.ahdi@gmail.com 


\section{PENDAHULUAN}

Citra suatu daerah tidak terlepas dari perilaku para pemangku kepentingan yang terlibat dalam pengelolaan daerah tersebut, di mana salah satu produk pengelolaan daerah tersebut adalah terpeliharanya tradisi lama yang dilakukan oleh ketua adat dan masyarakatnya. Salah satu daerah yang masih memelihara tradisi lama tersebut adalah Kampung Cireundeu, yang berusaha mempertahankan citra sebagai Kampung Adat yang konsisten mempertahankan tradisi Sunda buhun berupa perilaku ritual Suraan yang diselenggarakan setiap tahun di tengah arus modernisasi yang melingkupinya.

Perilaku yang diturunkan leluhur atau nenek moyang Komunitas Adat Kampung Cireundeu terhadap warga sebagai generasi penerusnya antara lain adalah kebiasaannya yang mengonsumsi rasi (beras ampas singkong) sebagai bahan pokok, cara mengolah lahan yang memiliki pola tersendiri, perilaku dalam mempertahankan prinsip leluhur dalam berhubungan dengan orang lain seperti tidak menyakiti orang lain, tetapi harus silih asih, silih asah, dan silih asuh, perilaku dalam mengambil keputusan dalam hal perkawinan, mengakses layanan pendidikan bagi anak-anaknya dan untuk memperoleh pelayanan sosial dasar bagi warga dengan cara yang diajarkan leluhurnya.
Perilaku lainnya yang biasa dilakukan oleh masyarakat adat Cireundeu adalah peringatan tahun baru Saka yang dilaksanakan setiap tahun pada tanggal 1 Sura yang disebut oleh masyarakat dengan istilah Suraan. Perayaan ini merupakan tradisi nenek moyang yang dapat diartikan sebagai Cara Karuhun Urang, dan dilandasi oleh kepercayaan Sunda Wiwitan yang bersumber pada ajaran Madrais atau agama Cigugur. Perayaan Suraan ini merupakan kearifan lokal, yang menurut Yulianti, telah mengakar pada masyarakat, sehingga terus dipelihara dan rutin dilaksanakan oleh komunitasnya (Yulianti, 2015).

Upacara satu sura yang dilakukan oleh masyarakat adat Cireundeu ini merupakan ungkapan rasa syukur kepada Sang Maha Pencipta atas nikmat dan karunia, keberkahan dalam hidup, kesehatan lahir dan batin yang diberikan oleh-Nya demi keberlangsungan hidup. Adapun makna dari upacara satu sura itu sendiri adalah ketika manusia hidup berdampingan dengan mahluk hidup lainnya, maka manusia harus saling memahami.

Masyarakat Kampung Adat Cireundeu adalah salah satu masyarakat etnis Sunda yang terletak dan menetap di Kelurahan Leuwigajah Kecamatan Cimahi Selatan Kota Cimahi. Komunitas Adat Kampung Cireundeu bukanlah masyarakat yang terasing. Di antara bukti bahwa komunitas adat ini bukanlah masyarakat yang 
terasing adalah dengan mereka tidak menutup diri dari pergaulan dengan dunia luarnya. Hal tersebut ditunjukan oleh adanya interaksi mereka dengan masyarakat luar dan mereka terbuka dengan para tamu yang berkunjung ke wilayahnya. Bahkan para tamu yang datang diperkenankan untuk tinggal di lingkungan mereka dalam beberapa hari dengan ketentuan bahwa setiap pengunjung harus tetap menjaga, memelihara dan mentaati adat istiadat yang berlaku di lingkungan setempat, hal tersebut dilakukan dengan tujuan menunaikan amanat karuhun (leluhur).

Komunitas Adat Kampung Cireundeu merupakan masyarakat yang taat dalam menjalankan amanat leluhur. Keadaan demikian tampak dalam sistem sosial yang diberlakukan dalam kehidupan sehari-hari, sehingga sampai dengan saat ini kehidupan masyarakat komunitas adat lebih bersifat apa adanya, mereka juga tidak tergiur dengan persoalan pemenuhan kebutuhan materi (duniawi) yang berlebihan, serta masih kuat dengan memegang teguh pikukuh (amanat) yang telah diwariskan secara turun temurun.

Keberadaan Komunitas Adat Kampung Cireundeu mencerminkan keindahan dan kehebatan pola pikir warganya. Pola pikir yang masih mengedepankan keseimbangan alam, keteguhan memegang kearifan lokal dengan bukti yaitu dalam mengolah singkong sebagai bahan makanan pokok yang telah dilakukan oleh nenek moyangnya.

Kentalnya tradisi Sunda Wiwitan yang masih dijalankan sampai sekarang semata-mata sebagai pembuktian dari sistem nilai, norma, pola pikir, pola sikap dan pola interaksi baik dengan sesama maupun dengan masyarakat luar. Tradisi tersebut diwarnai oleh pemaknaan terhadap realitas kehidupan dalam konteks sosial-budaya setempat.

Beragam simbol yang dipetukarkan oleh masyarakat Komunitas Adat Kampung Cireundeu dan digunakan untuk merepresentasikan apa yang dimaksudkan, dan juga digunakan untuk menyampaikan ide atau gagasan sebagai hasil interpretasi atas realitas yang mereka alami dalam kehidupannya. Begitupun pada ritual Suraan yang dilakukan Komunitas Adat Kampung Cireundeu yang menyimpan banyak simbol yang merupakan produk dan sekaligus sebagai kekayaan budaya setempat yang unik dan khas dalam bentuk simbolik, dari yang bersifat semiotis seperti penggunaan baju adat pangsi yang serba hitam, metaforis dilihat dari bahasa yang digunakan sehari-hari dan yang digunakan juga saat ritual seperti panjatan doa untuk karuhun, dan terkadang retoris, abstrak dan universal. Tentunya simbol-simbol tersebut tidak dapat dipahami oleh semua orang, namun tetap merepresentasikan fenomena yang terjadi. 
Eller menyebutkan bahwa:

Symbols, in the very simplest construction, are things-objects, images, sounds, actions, gestures, utterances, and almost any other medium-that - mean something, that - have a meaning. The - meaning is that which the symbol stands for, the phenomenon of which it is a representation or a place-holder. Moreover, the relationship between the symbol and its meaning is arguably arbitrary and conventional - that is, there is no necessary connection between the particular meaning and the particular symbol (Waluyo, 2015).

Tentunya beragam bentuk simbol yang digunakan tidak muncul dengan sendirinya, melainkan melalui proses pembubuhan makna. Fenomena simbolik pada perspektif komunikasi juga dipandang sebagai produksi sekaligus pertukaran makna sekalipun pertukaran makna tersebut berlaku secara lokal. Untuk meninjau simbol yang mengisyaratkan perilaku komunikasi maka diperlukan pembagian pada dua pengidentifikasian masalah yakni perilaku dapat ditinjau dari kaidah bahasa khususnya saat pelaksanaan ritual Suraan dan bagaimana aktivitas ritual Suraan yang terjadi di Komunitas Adat Kampung Cireundeu.

Kedua pengidentifikasian perilaku pada ritual Suraaan tersebut pada dasarnya merupakan aktivitas komunikasi ritual, yang menurut Mulyana, sesuatu yang biasanya dilakukan oleh komunitas yang sering dengan melakukan upacara-upacara berlainan sepanjang tahun dan sepanjang hidup, yang disebut oleh antropolog sebagai rites of passage (Manafe, 2011).

Maksud dan tujuan penelitian ini adalah untuk memperoleh deskripsi serta memahami perilaku komunikasi Komunitas Adat Kampung Cireundeu pada ritual Suraan. Penelitian ini merupakan studi etnografi komunikasi tentang culture suatu komunitas yaitu Komunitas Adat Kampung Cireundeu.

\section{METODE PENELITIAN}

Penelitian ini menggunakan pendekatan kualitatif yang dilakukan untuk mengamatai dan mendeskripsikan berbagai fenomena tentang perilaku manusia dalam lingkungan hidupnya, berinterkasi dengan mereka untuk memahami apa yang dipikirkan, dirasakan, dan dilakukan mereka tentang dunia sekitarnya. Hal ini bisa terjadi menurut (Artawan, Dewi, \& Budiana, 2016), karena pada penelitian kualitatif kedalaman makna tentang fenomena menjadi persoalan.

Adapun tradisi penelitian yang digunakan adalah etnografi komunikasi. Dengan pendekatan metode etnografi komunikasi dapat memberikan deskripsi, menjelaskan bahkan menyatakan adanya hubungan antara kategori-kategori dan data yang ditemukan. Ini sejalan dengan dari tujuan etnografi yaitu untuk menggambarkan, menganalisis, dan menjelaskan simbol-simbol budaya dari suatu kelompok sosial atau sub kultur. 
Untuk mendapatkan data penelitian, maka peneliti menggunakan wawancara mendalam, observasi partisipan, dan studi dokumentasi. Dalam penelitian ini penulis menggunakan perpanjangan keikutsertaan, ketekunan pengamatan dan triangulasi teori dan wawancara untuk menentukan keabsahan penelitian yaitu dengan menggunakan beberapa perspektif yang berbeda untuk mengintepretasikan data yang sama. Konsep yang digunakan tidak hanya menggunakan konsep komunikasi dengan fokus pada komunikasi kelompok dan ritual sebagai kajian utama penelitian ini namun juga digunakan konsep-konsep tentang komunitas adat, ritual, dan akulturasi.

\section{HASIL DAN PEMBAHASAN}

Salah satu ritual keagamaan besar yang sering dilakukan setiap tahunnya oleh masyarakat Kampung Cireundeu yaitu peringatan Tahun Baru 1 Sura. Ritual ini adalah adalah lebarannya penganut aliran kepercayaan yang dilaksanakan sebagai upacara nutup taun (Tutup tahun) dan ngemban taun (Menyambut tahun baru) Saka dalam penanggalan Sunda. Kegiatan ini merupakan kearifan lokal yang telah mengakar pada masyarakat, sehingga terus dipelihara dan rutin dilaksanakan oleh komunitasnya (Yulianti, 2015).

Peringatan Tahun Baru Saka yang deperingati oleh masyarakat adat Cireundeu dalam tradisi Jawa disebut dengan satu Suro, dan bertepatan dengan tanggal 1 Muharam, yaitu tahun baru Islam (Hijriyah). Antara tahun Hijriyah dengan tahun Saka yang digunakan pada zaman Sultan Agung dari Mataram untuk menggantikan Saka Hindu. Sebenarnya dulu, masyarakat Kampung Adat Cireundeu masih melaksanakan rapat untuk menentukan tanggal 1 Sura, tapi sekarang tidak lagi, karena 1 Sura diperingati bersamaan dengan tahun baru Islam.

Rangkaian Suraan ini dilaksanakan di Bale Saresehan (tempat berkumpul masyarakat adat) yang waktuya dari pagi sampai sore. Pada ritual Suraan terdapat serangkaian bagian yang terjadi. Hal ini diawali dengan perayaan hari raya dan diakhiri dengan hiburan wayang golek semalam suntuk. Seluruh masyarakat Kampung Adat Cireundeu ikut andil dalam rangkaian ritual ini, gotong royong yang menjadi falsafah hidup masyarakat, terasa sekali.

Mengawali rangkaian Suraan di Kampung Adat Cireundeu, masyarakat menggelar acara syukuran nganuhunkeun atas nikmat yang telah diberikan selama setahun ke belakang, acara yang mirip dengan Idul Fitri pada masyarakat Muslim ini dilaksanakan tepat tanggal 1 Sura di Bale Saresehan, di mana semua masyarakat menggunakan baju adat Sunda, pangsi untuk laki-laki dan kebaya putih ber-samping (kain batik yang dililit sebagai rok) untuk perempuan bermotif khas Cireundeu yaitu lereng kujang 
untuk bawahannya. Motif lereng kujang tersebut konon melambangkan budaya asli Sunda. Namun ternyata pemakaian samping disesuaikan dengan keinginan penggunanya, biasanya memakai kain samping khas Jawa Barat.

Sajian lainnya yang disediakan di Bale Adat di tengah ririungan warga dalam rangkaian hari "lebaran" tersebut adalah gunungan sesajen yang terdiri dari aneka ragam buah-buahan dan rasi (nasi singkong). Keunikan yang terdapat di kampung Cireundeu adalah makanan pokok yang dikonsumsi oleh masyarakatnya adalah nasi dengan bahan bakunya singkong. Hal ini dilakukan sejak jaman penjajahan Belanda (1918) sebagai wujud kepatuhan masyarakat adat Cireundeu terhadap wejangan leluhur adat.

Ritual upacara Satu Sura ini merupakan manifestasi dari rasa syukur masyarakat adat Cireundeu atas keberkahan yang diberikan Sang Pencipta, yang dalam pelaksanaannya telah terjadi perubahan dalam hal berpakaian, dimana sebelum tahun 2000-an, pakaian yang dikenakan oleh masyarakat merupakan pakaian baru, namun seiring dengan perjalanan waktu, pakaian yang dikenakan berubah, di mana kaum laki-laki memakai pangsi berwarna hitam, sedangkan untuk kaum wanitanya memakai kebaya atau pakaian berwarna putih. Perubahan model pakaian tersebut, merupakan implementasi dari pewarisan nilai yang bersifat simbolis dan bermakna introspeksi diri, dan pelestarian nilai-nilai luhur para leluhur (Waluyo, 2015).

Pelaksanaan ritual dari jam delapan lebih dan dilaksanakan ririungannya di Bale, dimana semua warga adat wajib berkumpul di Bale Saresehan bagi perempuan, dan laki-laki berkumpul di pendopo (panggung) diluar Bale. Yang berada di dalam Bale tentu jajaran kasepuhan yang ada di Kampung Adat Cireundeu dan juga panitia pelaksana acara seperti ketua dan pembawa acara.

Rangkaian acara ritual Suraan ini terbuka untuk masyarakat umum, tetapi dengan syarat masyarakat atau pengunjung yang datang tetap menghormati saat-saat ritual seperti wejangan dan $d u^{\prime} a$. Ketika Abah Emen sebagai sesepuh kampung Cireundeu memberi wejangan, masyarakat mendengarkanya dengan seksama, karena Ia merupakan salah satu tokoh yang memiliki karisma di mata komunitasnya. Karisma ini muncul dari pancaran kualitas kepribadian yang dapat membangkitkan 'pesona gaib', sehingga dikagumi oleh komunitasnya, seperti jujur, dapat dipercaya, tegas, konsisten, pemberani, dan cerdas (Hindaryatiningsih, 2016). Karisma ini pada akhirya sering melahirkan otoritas pada dirinya untuk membangun pengikut.

Acara ditutup dengan prosesi saling meminta maaf dengan ciri khas memercikkan 
minyak wangi ke tangan sebelum bersalaman. Aturan dalam menjalankan sungkem dimulai dari perempuan yang ada di Bale. Berbaris rapi, bergiliran memberikan penghormatan salam kepada sesepuh Kampung Adat, setelah itu dilajutkan dengan kaum pria yang menuruni panggung, ikut menyambung barisan menuju Bale untuk sungkem pada sesepuh. Di panggung pun semua warga menyambung barisan untuk saling bersalaman. Suasana saat sungkem sangat khusyu dan diwarnai dengang isak tangis haru dari setiap warga Kampung Adat Cireundeu. Suasana seperti ini tidak terlepas dari karisma sesepunya, dan hal ini dapat dijadikan model pewarisan nilai-nilai budaya kepada masyarakat lokal (komunitas), masyarakat sekitarnya, dan juga pemerintah sebagai pranata pendukungnya yang memiliki tanggung jawab dalam menyosialisasi dan mewariskan nilainilai tradisi masyarakat lokal kepada generasi selanjutnya (Hindaryatiningsih, 2016).

Selain melaksanakan sungkem, tidak jarang para warga juga mengajak bersalaman para pengunjung yang datang. Di sini perngunjung dilibatkan semata-mata dengan tujuan sebagai makhluk yang ada di dunia, meminta maaf pada sesama, agar dapat menjalani kehidupan dengan baik, saling menolong dan sebagai rasa toleransi antar umat dengan berbagai kepercayaan. Acara penutup yang paling terasa kekeluargaannya adalah makan prasmanan, dimana semua yang datang dipersilahkan mencicipi hasil bumi dan olahan singkong yang dibuat oleh para wanita di kampung adat.

Puncak acara yang biasanya dilaksanakan di pertengahan bulan Sura, atau saat akan nutup bulan Sura ini sepakat dilaksanakan pada 3 hari terakhir di Bulan Sura, menurut Kang Jajat, tanggal tersebut dipilih dengan kesepakatan bersama warga kampung adat (dimusyawarahkan) dengan pertimbangan dengan sesepuh. Rapat untuk menentukan tanggal dibuat terpisah dan tertutup. Menurut pemaparan Abah Iyu, penanggalan tidak dapat dibuat asal-asalan, namun banyak hal yang harus diperhatikan dan juga jangan sampai mengganggu warga lain di lingkungan luar Kampung Adat, karena hidup adalah berdampingan, selaras, baik dengan masyarakat sekitar, alam, dan semua isi di dunia. Ini merupakan pandangan hidup masyarakat sebagai bentuk tanggung jawab yang berkaitan dengan hak dan kewajiban sangat menekankan pada ketenteraman batin (Axiaverona, 2018).

Puncak acara ritual Suraan dilaksanakan dengan ritual yang dinamakan ritual "Damar Sewu" (seribu damar/obor) sebagai pembuka acara yang mirip dengan acara pembuka dalam upacara seren taun di Cigugur Kuningan, yaitu sebagai gambaran manusia dalam menjalani kehidupan baik sosial maupun pribadi. Namun di Kampung Adat Cireundeu, ritual Damar 
Sewu dilakukan lebih sederhana, tapi tidak serta merta meninggalkan esensi dari ritualnya tersebut.

Ritual Damar Sewu biasa diadakan pada malam hari (sekitar jam 7 malam). Ritual Damar Sewu di Kuningan dimulai dengan penyalaan obor besar yang ada di halaman gedung paseban Tri Panca Tunggal oleh seorang pemuda yang menunggangi kuda sambil membawa obor. Setelah obor besar menyala dilanjutkan dengan menyalakan obor obor lain yang berada di sepanjang jalan desa Cigugur, sehingga desa Cigugur menjadi terang benderang oleh cahaya dari damar yang banyak tersebut.

Pada saat pelaksanaan dari rangkaian ritual Suraan di Kampung Adat Cireundeu, ritual Damar Sewu diawali pukul 19.00 WIB. Sebelumnya, kira-kira jam 6 sore atau saat matahari mulai terbenam, saung yang berisi dengan hasil bumi sebagai persembahan dan tanda syukur kemakmuran Kampung diberikan dupa. Sehingga rangkaian ritual Damar Sewu sudah bisa dirasakan oleh warga dan pendatang yang datang, namun tidak banyak pendatang yang ikut menyaksikan pembakaran dupa, karena pembakaran dupa tidak dilakukan besarbesaran, hanya dilakukan di beberapa titik. Pendatang pun baru menyadari ada pembakaran dupa setelah aromanya tercium cukup kuat dan membuat suasana yang menjadi terasa khusyu, damai walaupun keadaan di sekitar Bale ramai warga yang masih gotong royong menyiapkan kursi dan kebutuhan acara.

Puisi yang berarti juga sebuah doa dan harapan ini sama juga sebagai sambutan kepada Sang Maha Kresa dan karuhun esensinya sama, nganuhunkeun sadaya keresana ke warga Kampung Adat sampai akhirnya masih bisa menikmati hasil bumi yang berlimpah, kesehatan jasmani rohani, dan juga kesempatan hidup di dunia. Setelah ngadu'a, dilanjutkan dengan prosesi seribu obor. Awal mulanya seorang (tokoh adat) memasuki kawasan Bale membawa sebuah obor yang sudah dinyalakan, lalu naik ke panggung, yang ternyata disana sudah ada empat orang nonoman atau anak muda yang duduk rengkuh membawa obor yang padam. Lalu satu per satu obor itu dinyalakan dan keempat nonoman berkeliling kampung menyalakan obor yang sudah dipasang di sepanjang jalan menuju Kampung Adat.Tentu saja semua yang dilaksanakan memiliki arti khusus.

Penutupan dari rangkaian ritual Suraan diawali oleh arak-arakan dari simpang tiga (jalan masuk ke Kampung Adat). Arak-arakan melibatkan semua orang termasuk pendatang. Pendatang atau wisatawan diperkenankan untuk membawa seserahan yang isinya adalah semua kuliner atau makanan yang terbuat dari singkong atau olahan singkong yang diproduksi oleh warga Kampung Adat Cireundeu. Seserahan 
tersebut disimpan di dalam nyiru (alat rumah tangga, berbentuk bundar, dibuat dari bambu yang dianyam, gunanya untuk menampi beras dan sebagainya).

Sebelum para pendatang masuk ke dalam kampung adat dan memulai arak-arakan, sebelumnya dilaksanakan ijab kabul. Ijab kabul adalah sebuah panjatan doa dari sesepuh yang disini adalah Abah Iyu yang meminta izin akan mengadakan kegiatan, agar acaranya berjalan lancar dan diberkahi. Juga ijab kabul ini dimaksudkan sebagai penyambutan dan ikrar janji khususnya pendatang bahwa tidak akan melupakan Tuhan Yang Maha Esa walaupun berbeda kepercayaan. Seperti mengingatkan bahwa hidup di dunia ini harus selaras, seimbang, baik dengan manusia dan juga alam.

Prosesi ijab kabul adalah dengan memegang sebuah kendi dari tanah liat yang diisi air dan daun hanjuang. Air yang digunakan pun bukan sembarang air, melainkan air yang dianggap suci dan tersebar di seluruh nusantara. Selain membawa hasil bumi, turut pula menyertakan nasi rasi tumpeng, tumpeng yang disajikan juga semua dari hasil panen dan ternak warga adat kampung adat. Jadi, di Kampung Adat Cireundeu, bukan hanya bertani, namun ada juga yang berternak, walaupun tidak banyak namun ternak dirasa cukup untuk memenuhi kebutuhan hidup sehari-hari.

Secara geografis, tumpeng merupakan tradisi purba masyarakat Indonesia terutama masyarakat Jawa yang wilayahnya dipenuhi gunung berapi tempat para hyang/arwah leluhur/nenek moyang bersemayam. Tumpeng yang sekarang dipengaruhi oleh budaya Hindu, sehingga berbentuk kerucut meniru bentuk gunung Mahameru tempat bersemayam dewadewi.

Yang menarik, di akhir rombongan arakarakan, ada tandu yang dibawa oleh 4 (empat) orang warga adat baik dari nonoman maupun dewasa. Tandu tertutup yang terbuat dari bambu ini berwarna putih dan beratap ijuk yaitu bagian dari atas dari pohon Palma yang besar dan tinggi, dapat mencapai $25 \mathrm{~m}$. Berdiameter hingga $65 \mathrm{~cm}$, batang pokoknya kukuh. Tandu itu berisi sebuah singkong yang berukuran agak besar dan diselimuti oleh kain berwarna putih. Setelah tandu singkong itu memasuki kampung adat, barulah para pendatang (wisatawan) diperkenankan memasuki wilayah kampung adat dengan menyambung rombongan yang sudah masuk terlebih dulu, disusul dengan kesenian angklung buncis yang dimainkan anak-anak memakai seragam warna biru langit.

Memasuki kampung adat, pendatang disambut oleh buah-buah pisang yang tergantung di sepanjang jalan menuju Bale. Buah pisang sengaja digantung di setiap penjuru kampung, bukan hanya di jalan besarnya saja. Hal tersebut dimaksudkan untuk menjamu para tamu yang 
datang. Pisang dipilih karena ternyata selain singkong, buah-buahan yang banyak hidup di lahan para warga adalah buah pisang. Tercatat menurut Kang Jajat dan Abah Widi, ada sekitar 70 jenis pisang yang tumbuh. Tidak heran, buah pisang yang disajikan di setiap sudut kampung ini berbeda jenisnya.

Selain disambut dengan buah-buahan yang tergantung di sepanjang jalan menuju Bale, ada pula anak-anak perempuan hingga remaja memakai kebaya putih khas Kampung Adat Cireundeu, mereka memainkan untuk menyambut para tamu yang datang, nada yang dimainkan tidak beraturan, maksudnya mereka hanya membuat kegaduhan yang membuat tamu semangat karena walaupun nadanya tidak beraturan tetap terdengar lembut dan suasananya menjadi terasa Sunda pisan.

Sebelum memasuki kawasan Bale Saresehan, rombongan warga adat, pendatang baik dari penghayat kepercayaan lain dan wisatawan, ditahan di lapangan yang sudah didekorasi sedemikian rupa, karena di lapangan ini akan diadakan prosesi ngajayak yang sebelumnya diawali dengan lengser dari warga Kampung Adat Cireundeu. Ki Lengser atau biasa disebut lengser saja merupakan salah satu tokoh dalam dunia kerajaan Padjadjaran yang dikenal sebagai pendamping sang prabu atau utusan perwakilan sang prabu yang turun dan menemui rakyat Padjadjaran kala itu.
Tokoh Lengser ini merupakan imajinasi masyarakat Sunda yang memiliki karakter unik. Tokoh ini digambarkan sebagai figur yang memiliki karakteristik polos, lucu, namun memiliki kecerdasan sehingga dianggap serba bisa. Tentulah sangat berbeda penggambarannya $K i$ Lengser utusan prabu dan Ki Lengser dalam ritual. Dalam upacara ritual, lengser digambarkan sebagai seorang laki-laki tua yang berpakaian sederhana dengan memakai baju dan celana pangsi, dan ikat kepala. Dalam menyambut para tamu, biasanya Ki Lengser didampingi oleh panyagan (pemain musik), pamaya (penari), dan punggawa (prajurit penjaga). Ki Lengser mengarahkan jalannya upacara dan mengarahkan para tamu hingga duduk di tempat yang disediakan.

Ritual ngajayak di Kampung Adat Cireundeu sendiri adalah ritual Penyembutan Padi, di Cigugur Kuningan, upacara ngajayak ini dilaksanakan pada tanggal 18 dilanjutkan dengan penumbukan padi dan sebagai puncak acaranya jatuh pada tanggal 22 Rayagung. Makna dari ngajayak ini adalah menerima dan menyambut, sedangkan angka 18 (dalapan welas) mengandung makna sebagai welas asih atau cinta kasih dan kemurahan Tuhan Sang Pencipta atas anugrah kemakmuran manusia dan alam semesta. Semua aktivitas tersebut merupakan implementasi dari komunikasi ritual, di mana menurut Manafe, pihak-pihak 
yang terlibat di dalamnya menegaskan kembali komitmen mereka kepada tradisi keluarga, suku, bangsa, negara, ideologi, atau agama mereka (Manafe, 2011).

Setelah prosesi ritual ngajayak, dilanjutkan dengan pentas kesenian warga adat, ada rampak kendang, umbul-umbul, diikuti dengan kaulinan barudak yaitu oray-orayan, permainan anak ular-ularan dalam Bahasa Indonesia atau kaulinan barudak oray-orayan dalam Bahasa Sunda termasuk pada dwiwacana atau kata berulang memakai akhiran -an yang artinya meniru atau menyerupai ular. Permainan ini dapat dimainkan oleh anak laki-laki dan perempuan atau campuran yang berumur antara 5 sampai 12 tahun. Biasanya permainan ini lebih dikenal di pedesaan dan dimainkan di halaman sekolah atau halaman rumah pada waktu pagi, siang, sore, bahkan malam hari rumah oleh murid-murid sekolah ketika bulan purnama.

Dulu, kaulinan barudak oray-orayan adalah sebuah permainan anak yang mayoritas berada dekat dengan alam (kebun atau lahan pertanian) dan pekerjaannya bertani. Ada pula nilai-nilai yang terkandung dalam permainan oray-orayan ini yaitu mengajarkan sedari ekcil tentang sportifitas, kerja sama, kerja keras, menghargai orang lain, dan yang penting adalah bersabar.

Permainan oray-orayan biasanya dilakukan oleh 7-20 anak dan tidak memerlukan alat bantu apapun hanya syair-syair yang dinyanyikan yang isisnya berupat tanya jawab di antara mereka. Permainan ini terdiri dari dua barisan (supaya terdapat dua kepala ular), dimana anak yang paling depan berperan sebagai kepala, yang tengah sebagai badan, dan yang belakang biasanya ditempatkan anak yang lebih kecil tubuhnya supaya lincah yang berperan sebagai ekor. Semuan anak-anak yang terlibat dalam permainan ini saling memegang pundak, kecuali anak yang paling depan.

Kedua kepala ular itu saling berhadapan. Setelah itu mulailah barisan atau ular itu berjalan meleok-leok mengikuti kepala ular seolah akan menerkam ekor ular lawannya. Oleh karena mereka mengatur posisi saling akan menerkam ekor ular, maka terdengar jerit dan tawa riang disertai lantunan lagu oray-orayan.

Selanjutnya, aktivitas komunikasi pada rangkaian ritual Suraan adalah menggunakan bahasa Sunda yang halus dan baik sebagai bahasa untuk menasehati (memberi wejangan) bagi masyarakat Kampung Adat Cireundeu. Budaya mereka selama ini, semua aktivitas yang dilakukan ketika rangkaian ritual Suraan memiliki makna yang khusus, yang terkadang orang tidak mudah untuk mengartikannya dalam waktu yang tidak sebentar dan kebanyakan orang yang merasa tidak mengerti dengan makna yang terkandung dalam untuk rangkaian ritual tersebut. Aktivitas pada saat ritual yang 
disampaikan dalam bentuk simbol-simbol dengan peralatan yang biasa digunakan.

Peranan ritual Suraan bagi masyarakat Kampung Adat Cireundeu yang bermayoritas pekerjaannya sebagai petani merupakan sebuah wujud syukur mereka kepada Sang Khyang atas kehidupan yang telah diberikan di dunia. Ritual Suraan ini merupakan ritual turun temurun yang dilakukan oleh masyarakat Kampung Adat Cireundeu yang bermayoritas pekerjaannya adalah petani.

Salah satu nilai kehidupan masyarakat Kampung Adat Cireundeu adalah gotong royong dan kerjasama. Ini pula yang terlihat dalam rangkaian ritual Suraan, ketika akan memasuki bulan Sura, hingga selesai bulan Sura ini, Bale sarasehan tampak seperti menjadi rumah bagi warga, hampir setiap hari tidak pernah sepi. Semua lapisan masyarakat mulai dari kasepuhan sampai anak-anak ikut membuat dekorasi di sekitar Bale. Ritual ini pada dasarnya adalah kegiatan komunikasi ritual, di mana para pesertanya dapat berbagi komitmen emosional dan menjadi perekat bagi keterpaduan mereka (Manafe, 2011). Hal ini dilakukan agar ritual Suraan dilaksanakan tepat waktu, karena mereka sadar rangkaian ritual Suraan bukan hanya untuk warga adat, tetapi juga terbuka untuk umum.

Kegiatan ritual Suraan ini merupakan implementasi komunikasi ritual yang bersifat sukarela yang dilakukan masyarakat secara turun temurun (berdasarkan kebiasaan) dan perilakunya telah ditentukan. Kegiatan ini pun bertujuan untuk mentransmisikan informasi tentang gagasan dan ide juga menyimbolisasi sesuatu yang dapat berpengaruh terhadap kehidupan bermasyarakat. Namun demikian, proses komunikasi yang terjadi dalam komunikasi ritual bukanlah berpusat pada transfer informasi, tetapi lebih mengutamakan sharing (berbagi) budaya bersama, sehingga proses transmisi pesan tidak menjadi tekanan utama (Andung, 2010).

Ritual Suraan merupakan sebuah aksi bukan hanya pemikiran dalam hal ini masyarakat Kampung Adat Cireundeu melaksanakannya bukan hanya sebagai pemikiran tanpa melakukannya. Kedua, dilakukan secara sadar dan bersifat sukarela, rangkaian ritual Suraan dilakukan secara sadar dan masyarakat setempat merasa tidak keberatan dalam melakukan ritual tersebut. Ketiga, irrational karena dianggap tidak bermanfaat, bagi orang luar, namun, masyarakat Kampung Adat Cireundeu memiliki makna berbeda dengan ritual Suraan tersebut. Keempat, bukan sebagai hiburan, masyarakat Kampung Adat Cireundeu menganggap ritual ini adalah khusus bukan sebagai hiburan, tetapi merupakan hal yang harus dilakukan dengan sungguh-sungguh. Kelima, dilaksanakan secara kolektif, hal ini terbukti dengan pengerjaan dan 


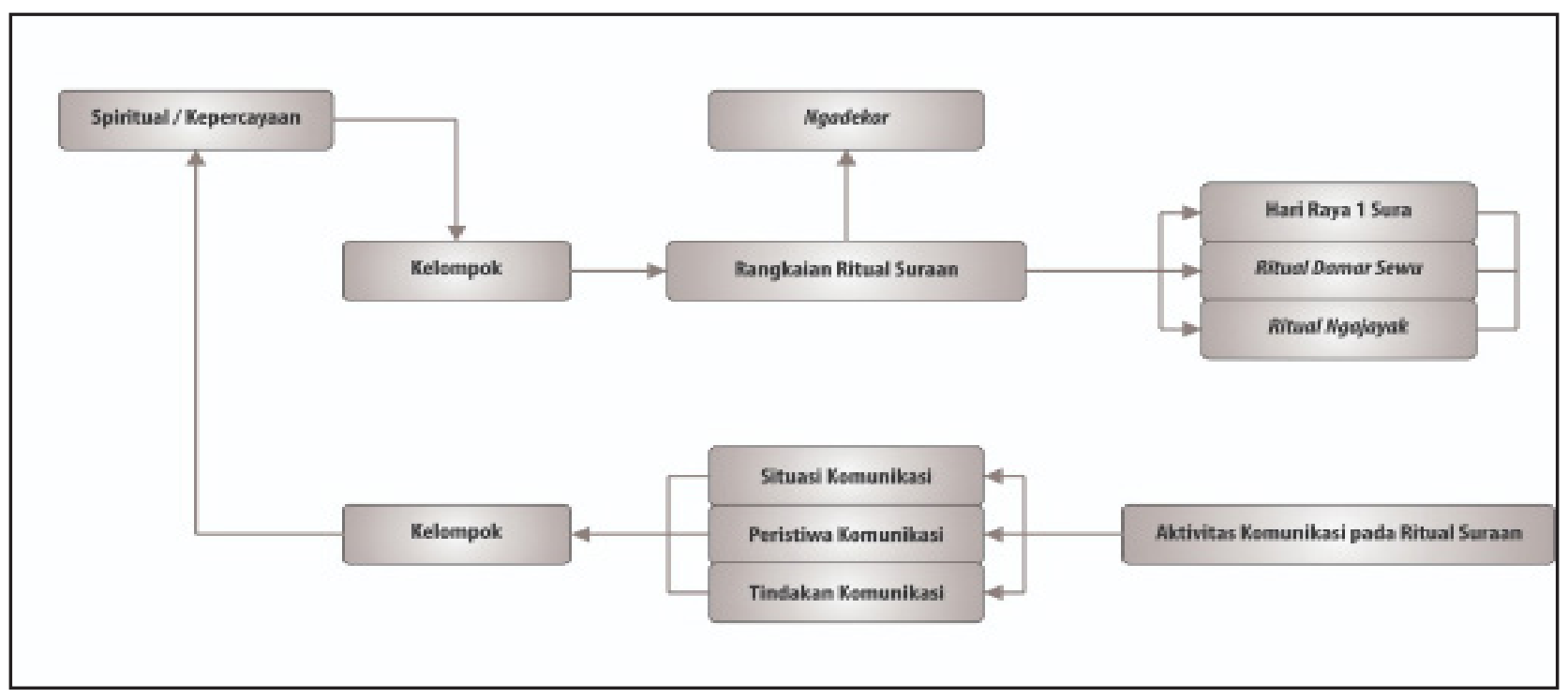

Sumber: Data Penelitian, 2018

Gambar 1 Aktivitas Komunikasi di Komunitas Adat Kampung Cireundeu pada Ritual Suraan

hasil panen dari setiap warganya.

Keenam, efektifitas simbol-simbol, dalam hal ini simbol-simbol yang ada dimaksudkan dengan tujuan dari ritual Suraan. Ketujuh, ekspresif, kegiatan ini merupakan bentuk ekspresi wujud syukur masyarakat Kampung Adat Cireundeu yang telah diberikan kehidupan yang layak, ditambah dengan kesuburan tanahnya. Suraan ini dilaksanakan sebagai harapan untuk dapat hidup layak di tahun mendatang, dan hasil bumi yang berlimpah, banyak dan unggul. Kedelapan, customary behavior, ritual Suraan ini diwariskan secara turun temurun dan bersifat kebiasaan. Kesembilan, regularly recurring behavior, kegiatan ini dilakukan secara berulang dan ditentukan mengikuti siklus waktu yaitu tutup tahun ngemban tahun Saka (Sunda). Kesepuluh, keramat, dalam ritual dan makna yang diberikan masyarakat Kampung Adat Cireundeu pada rangkaian ritual Suraan lebih tepatnya disebut dengan sakral. Karena ritual Damar Sewu dan ngajayak memiliki makna mendalam bagi masyarakat adat dan doa (rajah) itu merupakan simbol-simbol yang disakralkan untuk meminta sesuatu.

Ritual yang dilakukan oleh masyarakat Kampung Cireundeu menggambarkan situasi komunikasi yang berfokus pada jantung Kampung Adatnya, yaitu kawasan Bale Saresehan, tempat terjadinya ritual, juga dilakukan di gerbang masuk utama menuju kampung adat (simpang tiga). Situasi komunikasi di Bale, sebagai jantung Kampung Adat, biasanya di Bale banyak terjadi komunikasi antara baik sesama warga adat, maupun dengan orang lain (pendatang). Situasi komunikasi yang terjadi pada warga Kampung 


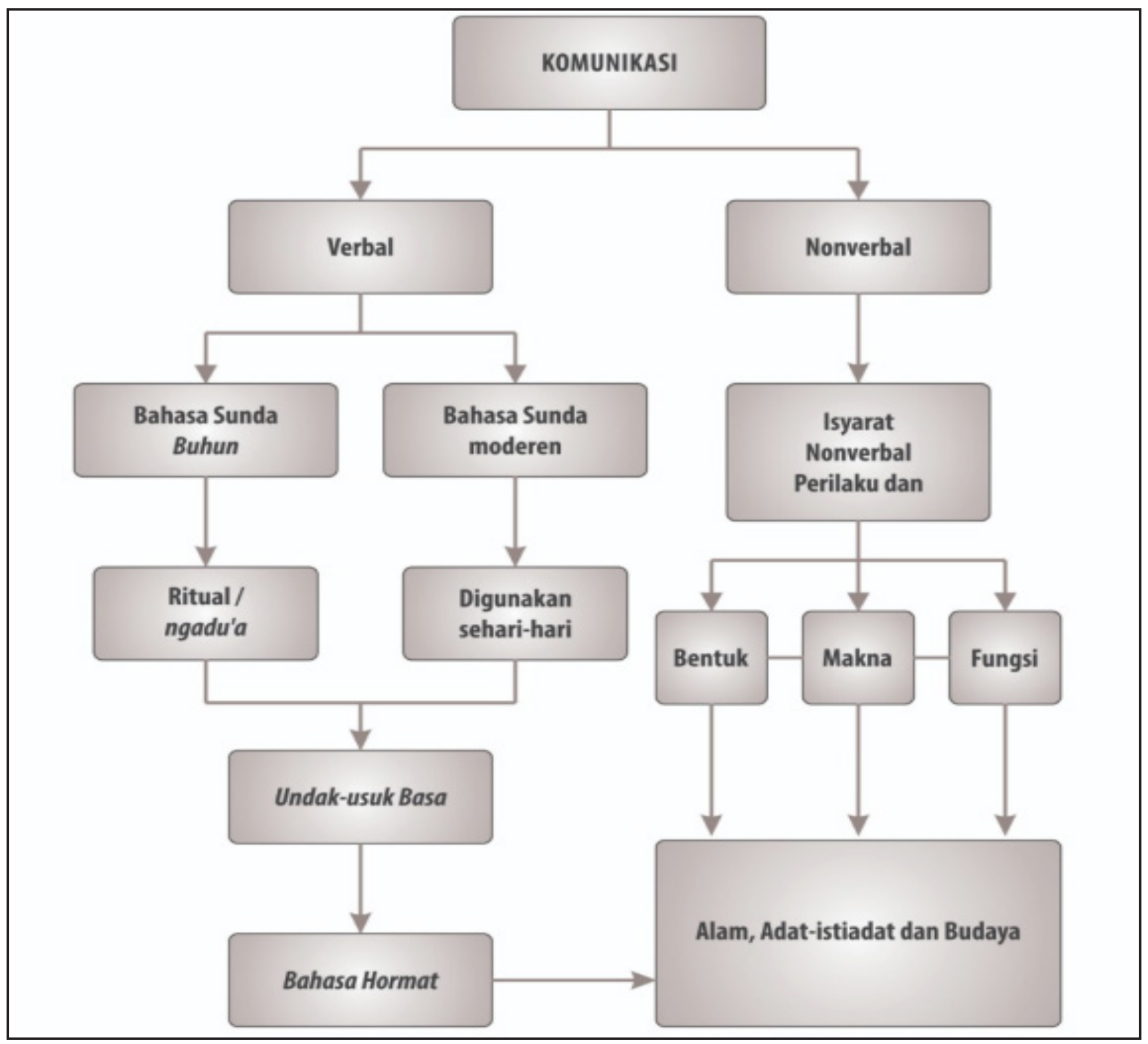

Sumber: Data Penelitian, 2018

Gambar 2 Pola Komunikasi di Kampung Adat Cireundeu pada Ritual Suraan

Adat ketika ngadekor merupakan situasi tutur berupa percakapan tentang segala aktivitas yang dikerjakan sehari-hari, maupun yang bersifat pribadi. Tidak jarang para warga adat pun saling memberikan teguran jika menilai sebuah perbuatan yang menurut mereka tidak benar (saling mengingatkan sesama manusia). Situasi tutur ini merupakan konteks terjadinya komunikasi yang tidak selalu komunikatif
(Iswatiningsih, 1994).

Situasi komunikasi yang dilakukan oleh semua warga adat yang ikut dalam tahapan ngadekor ini mementingkan pekerjaan. Tidak heran jika ada beberapa saat, suasana Bale cukup hening walaupun di sana sangat ramai. Lebih fokus bekerja ini juga dimaksudkan agar persiapan ritual yang akan dijalankan nanti cepat selesai. Jika bercermin pada masyarakat 
luar kampung adat, kadang pekerjaan banyak tertunda karena kebanyakan bicara. Namun, tetap saja, percakapan tidak dapat dihindari. Percakapan juga bisa dinilai lebih banyak atau berfokus pada tema besar tentang konteks kegiatan yang akan mereka jalani, misalnya seperti menanyakan hasil bumi yang masih belum disiapkan, atau alat dan bahan ritual yang masih belum kumplit, dan lain-lain. yang dipantau oleh Ketua adat (Abah Emen). Pada saat Ketua Adat ikut terlibat dalam pembicaraan, sehingga suasana menjadi hening, maka hal tersebut merupakan peristiwa tutur. Peristiwa tutur senantiasa bersifat komunikatif dan diatur oleh kaidah untuk penggunaan tutur (Iswatiningsih, 1994)

Ritual yang dilakukan oleh masyarakat kampung Cireundeu menggambarkan situasi komunikasi yang tidak terlepas dari konteks komunikasi dan konsep waktu saat melakukan aktivitas terjadinya. Konteks komunikasi biasanya berlangsung ketika berkumpul di Bale, baik siang hari, sore hari, bahkan hingga malam hari. Konsep waktu, hari, musim hanya memengaruhi topik obrolan yang disampaikan. Partisipan tetap sama begitu dengan proses komunikasinya. Namun berbeda saat melaksanakan ritual, yang dimana situasi komunikasi berubah sakral dan tertib. Saat prosesi ritual sungkeman, situasinya berubah menjadi haru, tidak jarang warga adat yang hingga meneteskan air mata saat melakukan sungkeman pada jajaran kasepuhan ataupun dengan keluarga dan kerabatnya. Situasi sungkeman ini dinilai sangat kekeluargaan, yang dimana warga adat juga ikut menyalami pengunjung yang datang saat ritual sungkeman di laksanakan. Persepsi perilaku tentu saja sesuai dengan tujuan komunikasi antarpribadi, dimana dilakukan oleh tuan rumah dan tamu yang datang.

Dalam melaksanakan rangkaian ritual melibatkan beberapa jejeran yang memimpin ketika ritual akan dilakukan. Jejeran ritual adalah mereka sesepuh Kampung Adat dan tokoh masyarakat yang dianggap bisa dan mampu. Selain jejeran, juga adanya Ki Lengser sebagai aktor utama dalam ritual Ngajayak. Komunikasi bisa terjadi dalam situasi apapun pada rangkaian ritual Suraan.

Pelaku rangkaian ritual Suraan ini juga melakukan komunikasi secara intens, dengan tujuan untuk berkolaborasi, bekerja sama agar segala sesuatu untuk melaksanakan ritual Suraan berjalan baik, dengan harapan tidak ada kekurangan apalagi terjadi kesalahan yang besar pada pelaksanaan rangkaian ritual Suraan. Maka dari itu, warga adat menjalin komunikasi dengan setiap warganya begitupun dengan warga sekitar dan pendatang yang ikut tinggal di Kampung Adat. Dengan demikian, ritual tersebut menunjukkan simbol kebersamaan, 
dan penghormatan kepada Tuhan Yang Maha Esa (Ngare, 2014).

Peristiwa komunikasi dapat tergambar dari beberapa tahapan yang dimana sebenarnya rangkaian ritual Suraan mengedepankan pagelaran atau pertunjukan seni, dapat dilihat bahwa cara ngadu'a pun seperti berirama ini menandakan bahwa "kesenian" mendominasi rangkaian ritual, ditambah lagi setelah ritual sakral dilanjutkan oleh beberapa kesenian khas seperti karinding, jaipongan, angklung buncis, gondang, dan yang lainnya dikemas dengan apik sebagai sebuah kesatuan ritual yang merupakan hasil dari pengalaman berdasarkan perjalanan sejarah Kampung Adat Cireundeu sebelumnya, sehingga semua ritual yang dilakukan tersebut menjadi sebuah realitas yang harus dipahami oleh generasi setelahnya. Peristiwa adat tersebut telah menggambarkan suatu fenomena citra kehidupan masyarakat adat. Dimana citra positif dapat ditunjukan melalui penyikapan terhadap berbagai peristiwa sosial yang terjadi, seperti pada kegiatan adat (Muchtar, 2016). Oleh karena itu, pemahaman pada realitas terbangun dalam serangkaian pengalaman, interaksi, dan konvensi komunikasi, sehingga melahirkan berbagai aspek penting dari kehidupan masyarakat (Fajrini, Bakti, \& Novianti, 2018).

Peristiwa komunikasi dapat tergambar dari beberapa tahapan yang dimana sebenarnya rangkaian ritual Suraan mengedepankan pagelaran atau pertunjukan seni, dapat dilihat dari tabel bahwa cara ngadu'a pun seperti berirama ini menandakan bahwa "kesenian" mendominasi rangkaian ritual, ditambah lagi setelah ritual sakral dilanjutkan oleh beberapa kesenian khas seperti karinding, jaipongan, angklung buncis, gondang, dan yang lainnya dikemas dengan apik sebagai sebuah kesatuan ritual yang dimana ketika seseorang melakukan kegiatan kesenian, misalnya menyanyi (dalam gondang), sesungguhnya orang tersebut telah melakukan tindakan sosial sebab menyanyi merupakan ekspresi diri yang diungkapkan menggunakan lambang atau simbol dalam bentuk suara dan ditujukan kepada orang lain, siapa pun orang lain yang menjadi sasarannya atau yang dituju. Namun demikian, hanya dirinya yang dapat memahami makna dari tindakan yang dilakukannya (Kinseng, 2017).

Namun demikian, tindakan sosial yang dilakukan para pelaku ritual Suraan tersebut baru bisa dipahami apabila para pelakunya mampu menjelaskan apa yang dilakukan dalam ritual tersebut, yaitu sebagai bentuk rasa syukur kepada Tuhan Yang Maha Esa, kalau kita berusaha menempatkan diri dalam dunia mereka. Jadi kita akan bisa memahami perilaku sesorang termasuk perilaku dengan benar manakala kita mampu berempati dan menempatkan kerangka pikir kita seperti apa yang ada dalam pikiran mereka (Taufiq, 2013). 


\section{SIMPULAN}

Lukisan tentang realitas pikiran, pengalaman batin, dan kebutuhan penggunanya secara simbolik tergambarkan oleh bahasa. Oleh karena itu, bahasa, dapat memengaruhi penggunanya dalam berpikir, melihat lingkungan alam sekitar secara berbeda, sehingga berpengaruh pula pada perilakunya dengan cara berbeda pula.

Makna simbol ritual Suraan mencerminkan perilaku komunikasi masyarakat Komunitas Kampung Adat Cireundeu yang memiliki kepercayaan Sunda Wiwitan, simbol dan semua maknanya kembali pada ajaran kepercayaan dan spiritualnya, dimana dalam rangkaian acara ini merupakan sebuah wujud syukur mereka kepada Sang Khyang atas kehidupan yang diberikan-Nya.

Dalam komunikasi ritual, tujuan lainnya adalah untuk memelihara ketertiban terhadap dunia budaya yang penuh makna yang dapat menjadi alat kontrol dalam tindakan atau pergaulan antar sesama manusia. Perilaku yang tercermin dari rangkaian ritual Suraan ini menunjukan sikap proactive dimana merupakan cara komunikasi yang cukup unik, karena orang yang memiliki pola komunikasi ini akan membuat sebuah pilihan reaksi terhadap sebuah rangsangan. Hasil buah pemikiran ini akan berbeda-beda dalam situasi dan kondisi yang menurutnya akan menghasilkan reaksi yang pas.

Ritual Suraan yang dilaksanakan oleh masyarakat Kampung Adat Cireundeu yang dilaksanakan setiap tahun merupakan tradisi warisan dari karuhun mereka. Dalam ritual Suraan, terdapat rangkaian ritual lainnya yang dilaksanakan secara terpisah, seperti ritual sungkeman yang merupakan ritual hari pertama (Hari Raya 1 Sura) sebagai pembuka, kemudian setelah dua sampai tiga minggu dilanjutkan dengan acara puncaknya yaitu ritual Damar Sewu selama tiga hari di panggung Bale. Setelah itu diakhiri dengan ritual Ngajayak yang dimulai dari jam 09.00 dimulai dari Simpang tiga sampai Bale Saresehan. Sebagai penutup dari rangkaian ritual Suraan tersebut digelar pertunjukan wayang golek semalam suntuk.

Perilaku komunikasi yang terlihat dari aktivitas komunikasi pada ritual Suraan ini termasuk pada perilaku terbuka, yang dimana masyarakat Kampung Adat Cireundeu merespons stimulus dalam hal ini rangkaian ritual dengan bentuk tindakan dan praktek (practice), sehingga masyarakatakan melakukan komunikasi sesuai dengan kebutuhannya. Selain itu juga, masyarakat Kampung Adat Cireundeu menunjukan sikap proaktif yang dimana sikap ini nilai cukup baik karena orang yang memiliki pola komunikasi ini akan membuat sebuah pilihan reaksi terhadap sebuah rangsangan. 
Ritual Suraan yang dilakukan oleh masyarakat Kampung Adat Cireundeu telah menunjukkan citranya sebagai kampung yang masih membangun, mempertahankan, dan memelihara kearifan lokal di tengah arus modernisasi.

\section{DAFTAR PUSTAKA}

Andung, P. A. (2010). Perspektif komunikasi ritual mengenai pemanfaatan natoni sebagagai media komunikasi tradisional dalam masyarakat adat boti dalam di kabupaten Timor Tengah Selatan, Propinsi Nusa Tenggara Timur. Jurnal Ilmu Komunikasi, 8(1), 1-10.

Artawan, G. A. W. M., Dewi, E. A. S, \& Budiana, H. R. (2016). Makna kegiatan unilever future leaders league bagi para peserta. PRofesi Humas, 1(1), 1-11.

Axiaverona, R. G. \& Soemanto, RB. (2018). Nilai sosial budaya dalam upacara adat tetaken. Journal of Development and Social Change, 1(1), 18-28.

Fajrini, N., Bakti, I., \& Novianti, E. (2018). City branding sawahlunto kota wisata tambang yang berbudaya melalui event sawahlunto International Songket Carnival (Sisca) 2016. Jurnal Profesi Humas, 2(2), 169-185.

Hindaryatiningsih, N. (2016). Model proses pewarisan nilai-nilai budaya lokal dalam tradisi masyarakat buton. Sosiohumaniora, 18(2), 108-115.

Iswatiningsih. (1994). Etnografi Komunikasi: Sebuah Pendekatan Dalam Mengkaji Perilaku Masyarakat Tutur Perempuan Jawa. In Seminar Nasional Prasasti (Pragmatik: Sastra dan Linguistik) pp. 38 45.

Kinseng, R. A. (2017). Struktugensi: sebuah teori tindakan. Jurnal Sosiologi Pedesaan, $5(2), 1-11$.

Manafe, Y. D. (2011). Komunikasi ritual pada budaya bertani atoni pah meto di timornusa tenggara timur. Jurnal Komunikasi, 1(3), 287-298.

Muchtar, K. (2016). Komunikasi politik dan pembentukan citra partai. Jurnal Ilmu Komunikasi, 14(2), 136-147.

Ngare, F. (2014). Studi komunikasi budaya tentang upacara ritual congko lokap dan penti sebagai media komunikasi dalam pengembangan pariwisata daerah manggarai provinsi nusa tenggara timur. Jurnal Ilmu Komunikasi, 1(1), 40-50.

Taufiq, A. (2013). Perilaku ritual warok ponorogo dalam perspektif teori. Jurnal Sosiologi Islam, 3(2), 113-121.

Waluyo, M. E. (2015). Nilai-nilai dan makna simbolik tradisi nganggung. Sabda: Jurnal Kajian Kebudayaan, 10(2), 1-15.

Yulianti, I. (2015). Pewarisan nilai-nilai budaya masyarakat adat cikondang. Jurnal Candrasangkala, 1(1), 1-22. 